\title{
H. F. AMEDROZ
}

BY the death of Mr. H. F. Amedroz in March of this year the country loses one of its most industrious workers in the fields of Isłamic history and law. Sprung from a Huguenot family, Mr. Amedroz was born in 1854, and educated at Winchester, where he gained a scholarship in 1866. He passed 1st the examination for Turkish Dragomans in 1877 , but was rejected on medical grounds. He was called to the Bar in 1882, and for several years was one of the Bar Reporters in the Chancery Courts. At this time he took up the study of Arabic with great keenness, and afterwards spent much of his life in research at libraries, both English and foreign, containing Arabic MSS., thereby becoming intimately acquainted with most of the contemporary representatives of the same study. In 1904 he published the literary remains of Hiläl al-Șābi, consisting of a large fragment of his Lives of the Viziers and a smaller fragment of his History. The first of these is one of the most interesting and instructive books in the Arabic language; in the main it is deroted to political biographies of the two most notable figures among the viziers of the 'Abbasids, Ibn al-Furät and 'Ali b. 'Isā, whose efforts to maintain the empire which had Muqtadir for its head were brave, but necessarily unavailing. The author himself belonged to a family which produced one of the most famous Secretaries of State, whence, though removed from the great viziers by a couple of generations, he had opportunities of hearing first-hand or nearly first-hand reminiscences of then. If the history of Baghdad, which has so recently become a British possession, were as familiar as that of Athens or Rome, Hilal's work on the viziers would be a favourite with a large circle of readers. Mr. Amedroz, who as an editor was among the most conscientious, instead of providing his texts with translations, furnished summaries of their contents in English; this plan has its merits for 
those who can read Arabic, but it is not calculated to render a work sufficiently accessible to those who are ignorant of its original tongue.

His second work on a considerable scale was his edition of Abũ Ya'lā Hamzah's Appendix to the History of Damascus, Leyden, 1908. This text starts with the events which led to the transference of Syria from the Eastern Caliphate to the Western, and treats of the Crusades up to 557 A.H. Mr. Amedroz introduced into the notes and appendices extracts from other unpublished chronicles illustrating and supplementing the statements of the text. The author, known as Ibn al-Qalannisi, is less attentive to detail than Hilāl, but is nevertheless highly instructive.

Mr. Amedroz's monographs on various topics appeared largely in this Journal, while others were printed in the German magazine Der Islam and the Italian Bolletino, etc. These are all characterized by thoroughness, and his legal training was evidently of help in the composition of those which dealt with questions of law. He was also a numismatist, and sent contributions to the journals which are concerned with that branch of learning.

The work which mainly occupied his time during his last years was a collection of unpublished chronicles dealing with the decline of the Caliphate under Muqtadir and his successors, and the rise of the Buwaihid dynasty. It is the hope of the present writer that he may be able to complete this task, which runs into many volumes.

Mr. Amedroz served on the Council of this Society from 1912 to 1915, and was one of the Gibb Trustees, taking a keen interest in the works issued by the Trust, as will be seen from the prefaces to Mr. Guest's edition of Kindi and the present writer's edition of Yäqūt. His wide and accurate knowledge was readily placed at the disposal of any, whether here or abroad, who consulted him.

D. S. M. 